\title{
The New Zealand's Recognised Seasonal Employer Policy and the Contractual Rights of Indonesian Workers
}

\author{
Lukas Banu * \\ Master of Law, Faculty of Law Udayana University \\ Matthew Gardiner** \\ Charles Darwin University School of Law
}

\begin{abstract}
The Recognised Seasonal Employer (RSE) scheme has attracted overseas workers to work in the horticulture and viticulture industries in New Zealand. They come from various countries all over the world, to stay and work in New Zealand. This article would explore some legal issues arise from New Zealand's RSE policy in particular relation with the Indonesian migrant workers who seek a job in New Zealand. It would also analyze the rights and obligations of the workers as stipulated in the employment contract concluded by the Indonesian workers and the New Zealand companies under the RSE scheme. The normative legal writing combines the research on relevant public and private legal instruments and comparatively examines both national law and regulations of Indonesia and New Zealand in order to afford a balanced insight of the law of both countries. This study found that on one hand, New Zealand laws have already covered all aspects of workers and determined New Zealand's government obligation to oversee the employment agreements, while on the other hand, Indonesian law and regulation do not cover explicitly the issue of protection of Indonesian workers who work in New Zealand under the RSE scheme. This article offers constructive recommendations addressed to any relevant stakeholders in order to improve the legal nature, institutional role and procedure for supporting New Zealand's RSE policy and in the same time the better protection to the Indonesian migrant workers.
\end{abstract}

Keywords: Recognized Seasonal Employer, Policy, New Zealand, Indonesian Migrant Workers, Employment Contract.

How to Cite (chicago-16th): Banu, Lukas, and Matthew Gardiner. "The New Zealand's Recognised Seasonal Employer Policy and the Contractual Rights of Indonesian Workers." Udayana Journal of Law and Culture 2, no. 1 (2018): 28-51. https://doi.org/ 10.24843/UJLC.2018.v02. i01.p02.

DOI: https://doi.org/10.24843/UJLC.2018.v02.i01.p02

\section{Introduction}

\subsection{Background}

There is a profound issue on acts of violence, including human rights, in various countries that put workers, including Indonesian workers, in a position of the victim which has caused the government of Indonesia to pay serious attention to the issues and subsequently assess the Indonesian policy on migrant workers. In 2012 the

* Corresponding Author: 1uc_chry@yahoo.com

** Email: mjgardiner@me.com 
government of Indonesia has decided a shock decision, to ban the placement of workers to foreign countries, such as Middle Eastern countries, including Saudi Arabia, which has no government to government ( $G$ to $G$ ) Memorandum of Understanding (MoU) with Indonesia or have no specific laws for protecting foreign migrant workers in their country. ${ }^{1}$ This policy has been instituted due to the number of foreign legal problems arising from bad relations between workers and employers that have emerged due to bad treatment, such as low salary, low standard of facilities, and no health insurance, into a more serious breaches of law, such as extreme working hours, punishments, and mental or physical violence.

Instead of that dark picture of the life of migrant workers in certain parts of the world, New Zealand has the opposite situation. Indonesian migrant workers have enjoyed excellent treatment within the country, such as good salary, well above standard facilities, housing and transportation, break time within working hours, well above standard cafés for enjoying their break times, holiday or perhaps leave, health insurance, and well above standard legal basis for the relationship between workers and employers which are all very well organized. This situation turns into good news for Indonesian workers and has caused New Zealand to become one of the top choices for finding a job. The good social atmosphere of the country has also encouraged Indonesian migrant worker to visit and stay in the country.

On another hand, Indonesian Workers have a high reputation in New Zealand; they are commonly recognized as high profile workers, with good behaviour, competent, committed, and consistent in their performance of their duties which has led the business entities in New Zealand to take into account the position of the Indonesian workers. ${ }^{2}$ Unfortunately, the problem arising out of the process of transferring of the workers, including those faced by the workers, has not been revealed by the Indonesian workers who are looking for a job in the country. Most workers are non-school graduates and have no ability to communicate in English. They mostly come from the lowest socio-economic group of people which see an opportunity for having a job as a golden opportunity. They are recruited and transferred to the country by labour brokers. Some of whom are dishonest in regards to the actual challenges faced by the Indonesian workers in the country. So, they deciding in the dark and accept the situation as it stands. ${ }^{3}$

1 Luqman Hakim and Anwar Fitrianto, "Political Economy of Sending Domestic Workers Abroad: Case Study of Indonesian Migrant Workers", Mediterranean Journal of Social Sciences 6, no. 4 (2015) ): 321. https: / / doi.org/10.5901/mjss.2015.v6n4p316

2 Kementerian Luar Negeri Indonesia. "Selandia Baru Sambut Baik 115 Tenaga Kerja Indonesia". https: / / www.kemlu.go.id/id/berita/siaran-pers/Pages / Selandia-Baru-Sambut-Baik-115-Tenaga-KerjaIndonesia.aspx

3 See Arbi Sumandoyo, "Berharap jadi TKI di New Zealand, Aryanto tertipu Rp 20 juta", Merdeka. Com, September 18, 2012; Detik News,"WNI Diimbau Waspadai Penipuan Tawaran Kerja di Selandia Baru”, January 27, 2010. 
New Zealand is a country located in the Southwestern Pacific Ocean and part of the British Commonwealth. The sustained economic growth of the country has produced a greater demand for workers, particularly temporary foreign migrant workers, due to the limitation population of the country and lower wage expectation. New Zealand is a country with a high-reputation for its distinct quality horticultural products and for sustaining its position economically they need support from other countries by means of providing temporary migrant workers. ${ }^{4}$ The government of New Zealand has covered these needs under the RSE scheme.

The scheme has enabled the temporary entry of overseas workers, which mostly from the South Pacific countries, to enter into and to work in New Zealand. It is worthwhile to reveal that many Indonesian citizens have also worked in New Zealand companies, although the RSE policy does not fully conform with the Indonesian law and regulations, particularly of those which cover the issue of protection over the Indonesian workers. This may also lead a question on an appropriate legal protection for Indonesian workers which is supposed to be conducted in the beginning and within the set up processes of the contract and then continue throughout its implementation.

This article will assess some of the legal issues arising from the New Zealand RSE policy, issues which may strongly affect the continued use of Indonesian workers. It particularly is concerned with the rights and obligations of the parties to the employment contract concluded by the Indonesian workers and New Zealand company drawn up under the RSE scheme. This article will also offer constructive recommendations addressed to any relevant stakeholders in order to improve the legal nature, institutional role, and the procedure of the development of employment contract, particularly those of which related to the placement of the Indonesian workers, under the New Zealand's RSE policy.

\subsection{Method and Structure}

This article has been developed under the policy-oriented approach, an approach requires a mixed formulation of method between normative and fact-based approach. ${ }^{5}$ The normative approach has been employed for searching and analyzing any legal instrument related to the employment contract, includes private documents, a model of employment agreement, ${ }^{6}$ international and regional legal instruments in order to

4 The three major categories of fruit are apples, grapes and kiwi fruit. The horticultural industry requires a large number of workers so that they are able to balance the high volume of seasonal work. The New Zealand government has been attempting to address this shortfall in employment by developing a guest worker program which allows companies to address the fluctuating labour market. Jhingan ML, Ekonomi Pembangunan dan Perencanaan, (Jakarta: Raja Grafindo Persada, 2008), 412.

5 Ida Bagus Wyasa Putra, "Teori Hukum dengan Orientasi Kebijakan (Policy-oriented Theory of Law)", (Denpasar: Udayana University Press, 2016), 118.

6 Private Agreements Employment Agreement, Contract between DMS Progrowers Ltd and Employee, Commencement Date 26 March 2017, Expiry date 1 October 2017. 
obtain the framework of protection of the rights of the migrant worker, and domestic law and regulation of Indonesia and New Zealand for gaining a balanced legal insights of the both countries. ${ }^{7}$ The fact-based approach has been conducted for extracting the normative message of the context, including the proper protection of workers, which necessary for supporting the improvement of the state legal policy and the private legal instrument. Under the approach, the message of the context is the compulsory material required for the input of law and policy improvement process.

This article is an advanced version of a jointly academic research conducted in Bali (Indonesia) and New Zealand in December 2015 which was commenced under the institutional research scheme of Udayana University. The research that has been held in Bali has covered most steps of the normative research including outlining process, exploring and analyzing the research materials, and also a small portion of the facts-based research, the interviews with the Indonesian government, agent and workers. The research that has been commenced in New Zealand was the contextual research which includes a visit to the company where the Indonesian migrant workers are working in the packhouse and in the orchard and visit to places where they are living. Interviews have also been done with the workers, the company's human resources, all levels of management, and the foundation facilitating the transferring of the worker from their origin country to the country destination. Despite the concern of the first author regarding the issues since 2007, some updated information has obtained by the author through direct observation and interview to DMS Pro-Growers management in New Zealand, 26 ${ }^{\text {th }}$ to $28^{\text {th }}$ of May 2017.

This article has been organized under the following structure: (1) the introduction, consist of background and method; (2) Result and analyses; and (3) conclusion and recommendation. The first section introduces the reason for the research and the method, including materials supporting the analyses. The second section performs some aspects of legal analysis, covers: the protection of migrant workers and their contractual obligations under the global concern as enshrined in some international and regional legal instruments; the analysis of the recognised seasonal employer policy of New Zealand; analysis of the results of comparative works regarding the legality of RSE's Employment Contract under Indonesian and New Zealand Laws, including a specific lesson learned from the practice of New Zealand's Company, namely DMS-Pro Growers, that recruits Indonesian workers under the framework of $\mathrm{RSE}$, including a legal analysis on the employment contract between the Indonesian

$7 \quad$ For example, Authors take note on publication made by Devi Melisa Damiri and Mohammad Benny Alexandri who carry out a comparative study concerning the level of non-standard employment relationships (initial workers- contract employees and outsourcing) in Nigeria and Indonesia found that there is not so much differences between the two countries. The study reveals that Nigerian labor laws differ between standard and non-standard workers in terms of rights and opportunities. This study reccommends that there is a need for concrete action on how government policies and regulations can work with companies that employ non-standard working relationships to protect workers and create more and better jobs. See Devi Melisa Damiri and Mohammad Benny Alexandri, "Industrial Relations: Comparative Non-Standard Employment Relationship in Nigeria and Indonesia”, Jurnal AdBispreneur 2, no. 1 (2017): 79-90. https:// doi.org/10.24198/adbispreneur.v2i1.12881. 
Workers and the company; and the analysis over the issues of documentation process, as well as the oversight mechanism and cooperation with the agents involved in the transfer of the worker. In the last section, the article summarizes the results of the legal analysis comprising all aspect of the analyses and offers some policy and technical recommendations.

\section{Result and Analysis}

\subsection{Global Concern on the Protection of Migrant Workers and their Contractual Obligations}

There are many international instruments that emphasize the needs of protecting of the lives and the livelihood of workers who work outside their home countries. The general guidelines on this particular concern have been drawn up under the Rio Declaration on Environment and Development which pay attention to the efforts of poverty eradication by means of improving peoples' standards of living and strengthening the rights of workers' participation in the shaping and implementation of the environmental and development strategies. ${ }^{8}$

Some International Labour Organizations (ILO) conventions have also addressed the issue in a certain way. The first example is ILO Convention No.143 which has set an obligation to the State Parties to take measures with regard to migrant workers in order to improve their awareness in regards to their rights and obligations and to provide equal treatment to ensure that the general and particular working conditions required by the Convention are properly fulfilled. ${ }^{9}$ Secondly, the ILO Convention No.97 has covered an issue of the employment contract. This convention requires the parties to the Convention which have an oversight mechanism of agreement or contract, have the obligation to undertake delivering a copy of the contract to the migrant worker before the time of their departure or at the reception centre in the arrival area of the immigration counters and also ordered that such employment agreement shall include provisions indicating the work conditions and remuneration. ${ }^{10}$ In addition, this convention also underlines the need for clarity of the means of enforcement of the contractual obligations of the employers. ${ }^{11}$

The International Convention on the Protection of the Rights of All Migrant Workers and Members of Their Families (ICMW) is one of the treaties that is strongly coloured by human rights legal concepts and comprehensively regulates the basic protection of the rights of migrant workers and their families. This convention

8 Rio Declaration on Environment and Development, Principle 29.

9 See Convention No.143 concerning Migrations in Abusive Conditions and the Promotion of Equality of Opportunity and Treatment of Migrant Workers, Art. 12 (c) and (g).

10 See Convention No.97 concerning Migration for Employment, Annex I Recruitment, Placing and Conditions of Labour of Migrants for Employment Recruited Otherwise than under Government-Sponsored Arrangements for Group Transfer, Art. 5 .

11 Ibid., Art. 7. 
is applicable to all components of the activities including preparation, departure, transit, the entire period of stay and remunerated activity in the receiving state (the State of employment), and the returning process to the State of origin. ${ }^{12}$ ICMW recognizes some rights of migrant workers related to an employment contract, including the right of the workers to address claims against any violation of any terms of the contract of work to the competent authorities in the State of employment. ${ }^{13}$ In this convention it is also clearly stated that a contract cannot be used as a means to derogate any internationally recognized rights of the migrant workers ${ }^{14}$ and it also prohibits any imprisonment and any kind of sanctions that may potentially produce an impact to the working permit and residential status to be imposed on migrant workers or their family members for any allegation of the failure to fulfil an obligation that has arisen from the employment contract. ${ }^{15}$

As Indonesia is the member state of the Association of Southeast Asian Nations (ASEAN), it seems necessary to observe any legal obligation under the ASEAN law which might prevail to Indonesia. In fact, Indonesia, the Philippines, and Vietnam have been grouped into the middle to low-income countries within ASEAN community which category was made under the consideration of those countries receive skilled workers from outside of the region and are the major countries of origin of the migrant workers who leave their country and go abroad seeking jobs. ${ }^{16}$

ASEAN $^{17}$ is aimed at, among other things, facilitating movement of business persons, professionals, talent and labour. ${ }^{18}$ ASEAN has created a human rights declaration that stipulates the rights of migrant workers as an inalienable, integral and indivisible part of human rights and fundamental freedoms. ${ }^{19}$ ASEAN also adopted a specific declaration which requires the sending states to enhance measures related to the promotion and protection of the rights of the migrant workers and to set up policies and procedures for facilitating their recruitment. ${ }^{20}$ This declaration, with regard to the employment agreement, has also held ASEAN countries to establish and promote legal practices to regulate recruitment of migrant workers and adopt

12 International Convention on the Protection of the Rights of All Migrant Workers and Members of Their Families, Art. 1 (2).

13 Ibid, Art. 54 (2). See also the same beared by project-tied worker in Article 61 (2).

14 Ibid, Art. 25 and 82.

15 Ibid, Art. 20.

16 Sophie Nonnenmacher, "Free Movement within the ASEAN", in Migration, Free Movement and Regional Integration, ed. Sonja Nita, Antoine Pécoud, Philippe De Lombaerde, Kate Neyts and Joshua Gartland (Paris: UNESCO - UNU-CRIS, 2017), 349.

17 Ibid, Art. 1 (5).

18 ASEAN Human Rights Declaration, para 4.

19 International Convention on the Protection of the Rights of All Migrant Workers and Members of Their Families, Art. 1 (2).

20 See ASEAN Declaration on the Protection and Promotion of the Rights of Migrant Workers, para 11 and 13. 
particular mechanisms for eliminating recruitment malpractices through legal and valid contracts. $^{21}$

\subsection{New Zealand's Policy on Recognised Seasonal Employer}

The RSE scheme is a policy launched in April 2007, ${ }^{22}$ which enables the temporary entry of overseas workers for employment into New Zealand's horticulture and viticulture industries. It was formulated for responding to the high demands of seasonal workers of New Zealand's companies focused their business on the farming and horticultural industry. The idea was developed from the apple production practices around Hasting in the eastern region of the North Island. Later, the kiwi fruit industry adopted such scheme to address its labour shortage in the seasonal production period.

The scheme is designed to address the domestic New Zealand concern of labour market shortages and, at the same time, to give an opportunity to foreign countries to take opportunity form the country's economic development. RSE is expected to overcome the lack of labour in New Zealand, as well as assist South Pacific countries to alleviate poverty in their home state. ${ }^{23}$

The New Zealand Government has used the RSE scheme to address labour market shortfalls and deliver aid to the communities in the Pacific Islands such as Fiji, Vanuatu, Tonga and Samoa. The New Zealand Government expected that under the program, the citizens of the said countries may indirectly earning benefit from the program, their standards of living might quickly be improved, as they are relatively close geographically to New Zealand. It has been proven by some countries, that the program has very much supported their social progress. They are the beneficiaries of this policy to develop social standards of living. Tuvalu, for example, has been facilitated by New Zealand's Department of Labour to take advantage from the seasonal employment opportunities in the horticulture and viticulture industries. ${ }^{24}$ For Vanuatu, RSE is a valuable sector of trade in services in the sense that the scheme has provided an opportunity to the low-skilled workers to get a job in a formal paid employment in New Zealand. ${ }^{25}$

The scheme of RSE has subsequently expanded by including other countries, such as Indonesia. The recruitment of Indonesian workers under this scheme was

21 Ibid, para 14.

22 Ema Hao'uli, “Triple Wins or Trojan Horse? Examining the Recognised Seasonal Employer Scheme under a Twail Lens", New Zealand Yearbook of International Law 11 (2013): 187.

23 Department of Labour of New Zealand "Final Evaluation Report of The Recognised Seasonal Employer Policies (2007 - 2009)", New Zealand, 2010: 5.

24 Charlotte Bedford, Richard Bedford, Elsie Ho, "Engaging with New Zealand's Recognized Seasonal Employer Work Policy: The Case of Tuvalu” Asian and Pacific Migration Journal 19, no.3, (2010); 423.

25 Ronald Ravinesh Kumar, 2012, "Migration and Development: The Development Impacts of Short-Term Labour Migration of Ni-Vanuatu Workers to New Zealand", Thesis, Masters of Arts in Development Studies, School of Government, Development and International Affairs Faculty of Business \& Economics Laucala Campus The University of the South Pacific: 108. 
based largely on the prior connections of some employers. ${ }^{26}$ Technically, employers in the said industries may apply for RSE status to supplement their labour supply with migrant workers. ${ }^{27}$ An Agreement to Recruit (ATR) is required before making a job offer to overseas workers. The ATR can only be approved by the government when the RSE status, inter alia, meets the condition for prohibiting the services of a contractor who does not meet the statutory obligations with regard to employment, health and safety and tax laws, or who uses illegal labour in fulfilling their need for workers. $^{28}$

\subsection{The Legality of The RSE's Employment Contract under Indonesian and New Zealand Laws}

\subsubsection{General Principles of Employment Contract}

Despite the existence of public laws and international arrangements that govern labour migration, many legal relations between migrant workers, recruitment agencies, employers, and insurers are also regulated by private contract. ${ }^{29}$ As with other international contracts, where one of the parties is a company subject to the laws of its home country, the rules in the contract shall fully comply the country's laws and regulations. Under Indonesian law, there are four requirements for the validity of agreements as stipulated in Article 1320 of the Indonesian Civil Code: ${ }^{30}$

1. there must be consent of the individuals who are bound thereby;

2. there must be capacity to conclude an agreement;

3. there must be a specific subject; and

4. there must be an admissible cause.

The rules of contracts are stipulated in the Indonesian Civil Code, ${ }^{31}$ which becomes the basis of the principle of freedom of contract. Wicaksono discusses the scope of the principle of freedom of contract to include: ${ }^{32}$

26 John Gibson and David McKenzie, "Development through Seasonal Worker Programs: The Case of New Zealand's RSE Program", Policy Research Working Paper 6762, The World Bank Development Research Group Finance and Private Sector Development Team, January 2014:11.

27 Ema Hao'uli, Op.Cit, 184.

28 L.A Winters, "New Zealand's Recognised Seasonal Employer Scheme: An Object Lesson in Policy Making - But for Whom?" (Toronto, Geneva and Brighton: ILEAP, CUTS International Geneva and CARIS 2016), 10.

29 Bassina Farbenblum "Governance of Migrant Worker Recruitment: A Rights-Based Framework for Countries of Origin”, Asian Journal of International Law 7, no.1 (2017): 165, https://doi.org/10.1017/ S2044251316000011

30 Indonesian Civil Code, English translation, https://www.tribunais.tl/files/Codigo_Civil_Indonesio_(Ingles).pdf

31 Ibid, Art. 1338 (1).

32 Frans Satriyo Wicaksono,Panduan Lengkap Membuat Surat-Surat Kontrak, (Jakarta: Visi Media, 2008), 3. 
a. the freedom to make or not to make an agreement;

b. the freedom to choose with whom an agreement will be drawn up;

c. the freedom to determine the content of the agreement;

d. the freedom to determine the object of the agreement;

e. the freedom to determine the form of the agreement; and

f. the freedom to accept or deviate from provisions of the legislation which is optional.

Meanwhile, the development process of contract law in Indonesia shall at least be performed in three steps, they are offer and acceptance, confirmation with the will, and the contract implementation. ${ }^{33}$ Ideally, a contract shall be formulated and drafted under involvement of both parties so their expectations could be firmly covered in the contract.

The involvement of the parties shall cause in a consequence either the workers will sign the agreement or not. Indonesian workers are presumed have no opportunity to accommodate their interests and to decide whether they shall sign or shall not sign the agreement and shall take or shall not take the opportunity for working in New Zealand in the shake of their personal economic needs. The workers are presumed would still expect an opportunity to put forward their considerations in the contract.

In New Zealand, the principles of the employment contract are provided in Employment Relations Act No. 24 (2000). ${ }^{34}$ The Commision of Law of New Zealand outlines the basic principles that make the contract binding under the New Zealand law, in which the parties to the contract shall establish the following elements: ${ }^{35}$

1. both parties intend to establish a legal relation when they enter into a contract;

2. one of the parties deliver an offer;

3. the other party accept the offer;

4. each promise contained in the agreement is made under a valuable consideration; and

5. all terms of the agreement must be clear and certain.

The contract shall contain the rights and obligations of parties and the consequences if one of the parties does not perform as agreed under the contract.

33 I Ketut Artadi and I Dewa Nyoman, Rai Asmara Putra, Implementasi Ketentuan-Ketentuan Hukum Perjanjian ke dalam Perancangan Kontrak, (Denpasar: Udayana University Press, 2010$), 77$.

34 New Zealand, Employment Relations Act No. 24 (2000), Part 6, Section 65.

35 Those elements are pharaphrased by Authors. See, Commision of Law of New Zealand, "Electronic Commerce Part One: A Guide for the Legal and Business Community", Report No. 50, Wellington, October 1998, para 50. http://www.lawcom.govt.nz/sites/default/files/projectAvailableFormats /NZLC\%20R50_0.pdf 


\subsubsection{Public Laws of Indonesia and New Zealand}

The Indonesian Constitution guarantees that every citizen of the Republic of Indonesia shall have rights to work and to earn a human livelihood. ${ }^{36}$ Under such human rights framework, the Constitution also recognizes that every person shall have rights to work and receive a fair and proper remuneration and employment treatment ${ }^{37}$ and shall also be free to choose job or jobs. ${ }^{38}$ In fact, there are no particular Indonesian legal frameworks or regulations that specifically and explicitly cover the issues of RSE. Some of them may be interpreted as providing a legal basis for the conclusion of RSE employment contract between an Indonesian migrant worker and the New Zealand's company, but it was not in an explicit formulation. Hence, it has produced a question on the legal certainty of the guarantee provided by the Constitution.

The Indonesian Act No. 39 of 2004 concerning the Placement and Protection of Indonesian Overseas Workers has covered the issue of the employment contract. The Act defines the contract as a written agreement between Indonesian migrant workers and a (foreign) employer that shall contain the terms of employment, rights and obligations of each party. ${ }^{39}$ This law determines the right of Indonesian migrant workers to get the original version of the employment agreement where they are one of the parties of the agreement ${ }^{40}$ and also obliges them to obey and performs jobs in conformity with the agreement. ${ }^{41}$

It also stipulates a general protection clause that recognizes the rights of Indonesian migrant worker candidates to be protected in accordance with Indonesian law in pre-placement, during the placement period, and after placement. ${ }^{42}$ Regarding the issue of the employment contract, this Act determines that the working relationship between employer and Indonesian migrant worker as an employee takes place after the employment agreement has agreed upon and signed by the parties. The Act also requires the presence of officials of the responsible government agency before the workers leaving his/her own country to the country destination. This employment contract shall be prepared by Private Indonesian Employment Placement Company (Perusahaan Pengerah Tenaga Kerja Indonesia Swasta, hereinafter, PPTKIS) ${ }^{43}$ and shall at least included: ${ }^{44}$

36 The 1945 Constitution of the Republic of Indonesia, Art. 27 (2).

37 Ibid, Art.28D (2).

38 Ibid, Art.28E (1).

39 Indonesia Act No. 39 Year 2004 concerning the Placement and Protection of Overseas Indonesian Workers, Art. 1 (10).

40 Ibid, Art. 8 (i).

41 Ibid, Art. 9 (b).

42 Ibid, Art. 55 (1), (2), and (3).

43 Ibid, Art. 55 (4).

44 Ibid, Art. 55 (5). 

a. name and address of the employer;
b. name and address of Indonesian migrant workers;
c. the position and type of work of Indonesian migrant workers;
d. rights and obligations of the parties;
e. conditions and terms of employment covering wages and wages work;
f. payments, both leave and rest periods, facilities and social security; and
g. extension period of work.

The Act does not mention the way the assistance of the governmental agency shall be provided and what are the benefits of their presence, for visiting or providing certain functions for the worker and for ascertaining the fulfilment of requirements determined by the Act.

The Indonesian government has issued an implementing regulation for administering the performance of the rules under the Act that is Regulation of the Indonesian Minister of Manpower and Transmigration No. PER.19/MEN/V/2006 concerning The Implementation of Placement and Protection Indonesian Overseas Worker which determines that the PPTKIS is under obligation to ensure that the candidate of the Indonesian migrant workers shall participate in a final briefing before Departure which is organized by the Indonesian National Agency for the Placement and Protection of Migrant Workers (Badan Nasional Penempatan dan Perlindungan Tenaga Kerja Indonesia, hereinafter, BNP2TKI). ${ }^{45}$ The briefing will introduce the existing public laws in the receiving countries such as the relevant law of immigration, employment, criminal provisions, employment contract, and some additional general knowledge. ${ }^{46}$ Regarding employment contract, the prospective migrant workers will get a briefing on the following issues:

a. the rights and obligations of both Indonesian migrant workers and their employers;

b. wages, working time, rest/leave, insurance;

c. type of work;

d. the term of the employment agreement and procedure extension of employment agreement; and

e. means of problem-solving or dispute settlement.

In addition, this briefing will also tell them to understand the customs and culture, the dangers of narcotics and HIV/AIDS, possible job risks in the placement

45 Regulation of the Indonesian Minister of Manpower and Transmigration No: PER. 19 / MEN / V / 2006 concerning Implementation of Placement and Protection of Indonesian Overseas Worker, Art.19 and 20 (1).

46 Ibid, Art. 23 (1) (a) (1). 
country, remittance procedures, spiritual mental coaching, and travel documents and implementation of the trip.

A legal issue can be found in a requirement of a certificate of competence and educational background of the employer. On one hand, Indonesian law explicitly requires Indonesian migrant workers to hold a certificate of competence ${ }^{47}$ and minimum educational background (junior high school), ${ }^{48}$ but on the other hand, RSE program does not require such certificate and educational background. As previously explained, RSE scheme has been developed for helping the alleviation of poverty in the origin country and to give benefits to workers, in which many of the Indonesian peoples expecting that the government will have such particular concerns on the issues.

At the lower level, the provincial policy in the Province of Bali conforming the central government regulation has published a Circular of the Governor of Bali No. 562/4729/III.2/Disnaker, dated 25th July of 2005, on the Placement of Indonesian Workers Abroad, but limited to a position for providing a recommendation for filling a job vacancy with a letter of formal intermediate skills. It has been outlined as a requirement in the MoU signed by the agents, foundations and PPTKIS in order to get approval from the government. ${ }^{49}$ For some extents, such provincial policy has not fulfilled the aims of RSE scheme utilised by DMS and the agency in New Zealand, as the RSE much more focused on the empowerment of the socio-economically challenged for those who do not have education and skills.

The law and regulations drawn up above have not been able to fully anticipate or resolve the problems faced by the Indonesian workers in the RSE program. It has caused further problems with the position of the workers. There are many different parties involved in the process of the placement of the workers during the recruitment process, the placement and supervision or monitoring over the workers. So, there is an unclear understanding of the roles and responsibilities of each party, including the workers themselves.

As a practical breakthrough, MoU is an effective instrument to support the RSE practice. For example, a MoU is adopted among PPTKIS, the agent in New Zealand, and the Indonesian Foundation that explains the role of each party. PPTKIS, for example, has a legal standing to send the workers abroad, arranging any legal document that is required for sending Indonesian workers from Bali to New Zealand. Next, the agent in New Zealand provides the job opportunity in New Zealand and ensures the standard of remuneration. The Indonesia Foundation in Bali is authorized to recruit a candidate of workers who will work in New Zealand.

47 Ibid, Art. 51 (d).

48 Indonesia Act No. 39 Year 2004 concerning the Placement and Protection of Indonesian Overseas Workers, Art. 35.

49 Memorandum of Understanding between Lubeck Management Group, Auckland, New Zealand, Yayasan Tangan Pertolongan Bali, Bali, Indonesia and PT. Bali Duta Mandiri, Bali, Indonesia signed December 2015. 
In general, New Zealand recognizes a human rights approach to be applied in employment matters. ${ }^{50} \mathrm{~A}$ fixed-term employment contract is generally used and favourably offered by New Zealand companies in creating a legal obligation of a foreigner who applied for working under the RSE scheme. This kind of Fixed-term employment contract has a legal basis under the New Zealand law. According to Employment Relations Act, a company and workers might agree with the term that the employment engagement will end at the close of a specified date or period; or in the occurrence of a specified event; or at the conclusion of a specified project. ${ }^{51}$

The law further regulates that both parties shall agree prior to the employment of the worker that it will end in such way, the company must have genuine reasons based on a reasonable grounds for specifying that the employment of the worker is to be terminated and give suggestion the worker of when or how his or her employment will end and the reasons for his or her termination. ${ }^{52}$ This Act also clearly state that a company cannot use three reasons as 'genuine reasons' to end up the employment, are: to exclude or limit the rights of the employee under this Act; to establish the suitability of the employee for permanent employment; or to exclude or limit the rights of an employee under the New Zealand Holidays Act No. 129 (2003).

\subsection{Lesson Learned From a New Zealand Company that Recruits Indonesian Workers under the RSE Scheme}

\subsubsection{Direct Management Services Pro Growers}

Direct Management Services (DMS) Pro Growers is a company that has taken up the opportunity to implement RSE scheme. ${ }^{53}$ It is a company jointly established in 1989 by Craig Greenless and Paul Jones and centred its administration in Tauranga City, New Zealand. It performs its business in more than 100 orchards which operated by 70 full-time staff. During the annual harvest period of kiwifruit at packhouses in Te Puna and Te Puke, DMS employs more than 500 seasonal workers. ${ }^{54}$ Along with DMS motto 'increasing grower profit', its post-harvest company-DMS Pro growers-share equally the ownership with growers and founding partners. ${ }^{55}$

DMS has started recruiting Indonesian workers in 2007. The first time DMS recruited 12 Indonesian workers under the facilitation of Lubeck Management Group, a management group which that was not exclusively working for DMS but also provided a network to other New Zealand companies that have business in the

\footnotetext{
50 New Zealand, Human Rights Act No.82 (1993), Art. 22.

51 New Zealand, Employment Relations Act No. 24 (2000), Part 6, Section 66 (1).

52 Ibid, Section 66 (2).

53 Employment Agreement (Fixed Term), Contract between DMS Progrowers Ltd and Employee, Op.Cit.

54 http://www.dms4kiwi.co.nz/who-we-are/history/

55 Ibid.
} 
kiwi fruit industry such as Eastpack, Satara, and Seeka. This management group has now been formalised by the New Zealand Government to carry out official services for RSE program. ${ }^{56}$

\subsubsection{Employment Contract between Indonesian Workers and DMS-Pro Growers}

The employment agreement between DMS and its Indonesian workers is drafted in the English. A good faith principle is implied as this contract also translated into Bahasa (Indonesian language). As explained by a DMS worker recruitment agent, this translation was made to enable Indonesia workers to have a clear understanding with regard to the content of the contract as well as to ensure that they could realize their rights and obligations stipulated in the contract. This way of drafting contract is an important aspect of the contract legal basis as the contract contains many technical legal terms comply with the New Zealand's Employment Relations Act 2000.

One of issue arisen in relation to the legal protection for Indonesian workers who work in DMS is the process of negotiation and implementation of the contract. Normally, all parties should be involved during the process of negotiation of the employment contract. Instead of a negotiating-model contract, DMS provides a fixed contract for efficiency reason. Provisions contained in this model of the contract have been predetermined and approved by both the Indonesian and New Zealand Authorities. Such fixed-term contracts give only two options to the Indonesian workers: to agree and sign the contract or disagree and refuse the contract. ${ }^{57}$ In this situation, workers almost have no opportunity to include their individual interests and consideration into the contract.

This practice is not in line with the Posner's bargaining theory that conceives consideration as a requirement of the validity of the contract. ${ }^{58} \mathrm{He}$ also discusses the basic concepts of economic analysis of law, ${ }^{59}$ which puts forward the concepts of rational choice, value, efficiency, and utility. ${ }^{60}$ The concept inspires people to find the happiness and increases the wealth. In connection with RSE, people are choosing to come to New Zealand for jobs because there is a scarcity of opportunity in their home countries. Referring to the theory, the employment contract between Indonesian workers and DMS implies a problem that needs to be resolved in a fair and equitable way in respect with both parties' rights and obligations under their respective laws.

It can be assessed that the contract provided by the DMS for the potential

56 Information obtained by First Author.

57 Employment Agreement (Fixed Term), Contract between DMS Progrowers Ltd and Employee, Op.Cit.

58 Fajar Sugianto, Economic Approach to Law (Jakarta: Kencana Prenada Media Group, 2013), 30-31.

59 Tomasz Famulski, "Economic Efficiency In Economic Analysis of Law", Journal of Finance and Financial Law 3, no.15 (2017): 29-30. http://dx.doi.org/10.18778/2391-6478.3.15.03

60 Fajar Sugianto, Op.Cit, 33-40. 
Indonesian workers has met some aspects of the principle of freedom of contract as has been discussed in Section 2.3, but clearly, it has not comprehended all of its aspects. In their participation in the RSE program, DMS uses generic employment contracts. These contracts have been duplicated and used extensively with all workers who participate in the RSE program, including those who are from the South Pacific region. Although it is generic in nature, the RSE contract model remains binding on behalf of the company's expectation and it has not covered the expectation of the Indonesia workers. Then, under the civil law principle of pacta sunt servanda it shall be legally valid and binding upon the Indonesian workers. So, technical contract assessment is firmly needed in order to determine the equal respect to each expectation of the parties.

The DMS employment contract has covered similar content to the content that has been discussed under Section 2.3, which are:

1. rights and obligations of Indonesian workers and DMS;

2. wages (in accordance with New Zealand's RSE Policy and Wages Protection Act of 1983), working hours (average 30 hours per week), day off and insurance;

3. type and location of working place, namely DMS Pukepack in Te Puke and DMS Te Puna in Te Puna;

4. period of work contract, 6 months and 1 day; and

5. problem-solving regarding employment relationship problems and terms about the choice of law, New Zealand's law.

The content of the contract has relatively satisfied the expectation of the parties. It has been expressed in the interview results of the different parties, which a particular note with the individual problems of the workers, homesickness, especially for those who are for the first time away from their family.

\subsection{Documentation Process}

There is a need for investigating the issue of documents to Indonesian foreign workers. ${ }^{61}$ Indonesian law requires prospective Indonesian migrant worker to have some particular documents, including an employment agreement and an employment placement agreement ${ }^{62}$ these have not been resolved under the DMS legal framework scheme.

61 Adharinalti, "Perlindungan terhadap Tenaga Kerja Indonesia Irregular di Luar Negeri (Protection of Irregular Indonesian Workers in Overseas)", Jurnal Rechtsvinding: Media Pembinaan Hukum Nasional 1, no. 1 (2012): 171.

62 Act No. 39 Year 2004 concerning the Placement and Protection of Indonesian Overseas Workers, Art. 51 (h) and (i). 
Indonesian law requires PPTKIS to have a licence of deployment issued by Indonesian Minister of Manpower ${ }^{63}$ and a letter of recruitment issued by BP3TKI. ${ }^{64}$ The law also requires endorsement by authorized officials at the Indonesian Embassy in Wellington, New Zealand for some of the documents including the copy of placement cooperation agreement between PPTKIS and its partner, job order/employment order/demand letter, and draft of the employment contract. ${ }^{65}$

The following explains the documentation process of the DMS recruitment for the Indonesian workers from the Province of Bali, in which most of the information is obtained from documents, observation on the practice and interviews. The document processes required under the RSE program begins from the application to recruit the workers to be submitted by the DMS to Department of Immigration of New Zealand, the application contains the reason for recruitment and also the number of workers that are expected by the company and the duration of employment. The New Zealand government then releases the Agreement for Recruitment (ATR) according to the application and evaluation.

The DMS continues the process by establishing a network with an agency in New Zealand that has an access to the Indonesian workers and provides the work agreement between DMS and the workers. The agency subsequently establishes a MoU to enable itself to perform its function as a representative agency, located in Bali. The agency then releases a Letter of Offer to the PPTKIS which outlines the number of workers needed and also the criteria of how they will be employed. PPTKIS continues this application by requesting an approval from Indonesian Ministry of Manpower. Once PPTKIS has received the approval, it will send the document to the agency in New Zealand for a ratification.

Ideally, the recruitment should only be started after PPTKIS receive a license of deployment. Unfortunately, this is not feasible due to the tight timeframes required by DMS to fulfil their requirements. In practice, the recruitment by PPTKIS has already been started before they hold the licence of deployment. This is to enable the potential workers to be available when the approval is received. Therefore, the requirements for documents, medical check-ups, ${ }^{66}$ and some other arrangements have been performed in advance, prior to the holding of license for deployment.

There are numerous forms of documents required for the prospective Indonesian workers. The first and perhaps the most important document is an ordinary

63 Ibid, Art. 32 (1).

64 Regulation of the Indonesian Minister of Manpower and Transmigration No: PER.19 / MEN / V / 2006 concerning Implementation of Placement and Protection of Indonesian Overseas Worker, Art. 6 (1).

65 Act No. 39 Year 2004 concerning the Placement and Protection of Indonesian Overseas Workers, Article 32 (3) and Regulation of the Indonesian Minister of Manpower and Transmigration No: PER. 19 / MEN / V / 2006 concerning Implementation of Placement and Protection of Indonesian Overseas Worker, Art. 3.

66 Regulation of the Indonesian Minister of Manpower and Transmigration No: PER.19 / MEN / V / 2006 concerning Implementation of Placement and Protection of Indonesian Overseas Worker, Art.18. 
passport. ${ }^{67}$ It is a document issued by the Government of the Republic of Indonesia to its citizens that enable them to perform interstate travels. ${ }^{68}$ The creation of new passport contains some particular issues. Most workers who apply for a visa for working overseas have never travelled overseas. An officer in the Immigration Office in Denpasar-Bali, an office operated under the Ministry of Law and Human Rights authorized for issuing passports, ${ }^{69}$ explained that the office has actually supported and facilitated the candidates who apply for passport under the framework of RSE program, ${ }^{70}$ but it takes time as they have to ensure all precautions have been fulfilled by checking the correct submitted documents and information in conformity with the law and regulations.

\subsection{Oversight Mechanism and Cooperation with Agents}

The recruitment of Indonesian workers under private to private engagement is continuously plagued with problems. ${ }^{71}$ There may be more problems that have not been discovered which potentially undermine the values of the program. For such reasons, the Indonesian government has actively been involved in the process of placement and protection of the Indonesian workers in order to increase the benefits of the program either for the workers, the private sectors, and the governments of both the origin and the host country. The aim of this involvement is to control or even to eliminate the source of these problems. In 2004, the Indonesian government, in supporting such an effort, published an Act No. 39 Year 2004 concerning the Placement and Protection for Indonesian Overseas Workers.

PPTKIS has been criticized for violations with regards to the implementation of the employment contracts of the Indonesian workers. Hence, they were forced to resolve the breach and enter a strong commitment to prevent such kind of breach reoccurring. ${ }^{72}$ In terms of procedural violations, some PPTKIS' have performed services with no operational license, some companies placed migrant workers who were not supported with job orders and distributed to the type of work which did not comply with the original signed contract. ${ }^{73}$ These are substantive issues related to the misbehaviour of the entity. The PPTKIS often charges a fee for placement above

67 This ordinary passport is used to make clear some other type of pasports e.g. diplomatic passport and official passport.

68 Indonesian Act No. 6 Year 2011 concerning Immigration, Art. 1(16).

69 Ibid, Art.26 (2).

70 Interview with Setyo Budiwardoyo, Head Section of Information and Immigration Communication Means, in Denpasar on 1st December 2015.

71 Sawitri Yuli Hartati, "Peranan Perusahaan Penempatan Tenaga Kerja Indonesia Swasta (PPTKIS) Dalam Perekrutan Calon TKI Ke Luar Negeri Melalui Skema P To P”, Social Justicia 1, no. 4(2017): 143.

72 Meita Djohan Oelangan, "Implementasi Perjanjian Kerja Dalam Penempatan Tenaga Kerja Indonesia ke Luar Negeri," Pranata Hukum 9, no. 1 (2014): 56.

73 Ibid. 
the official amount determined by the law, recruited underage workers (children), and supplied a poor quality of information to the prospective migrant workers. ${ }^{74}$

Undoubtedly, the Indonesian government has the authority to manage the oversight mechanisms ${ }^{75}$ unfortunately, the enforcement does not prevail as the government is less powerful in controlling all aspects of the procedure. This includes the limited access to the company and the agents. In this situation, Indonesian Government should consider closer co-operation with the agents in New Zealand to prevent any acts of exploitation against the Indonesian workers. There are at least three reasons the cause the agents to play such a crucial role in providing legal protection for Indonesian workers in New Zealand, such as:

a. The geographical position. The agent is located in New Zealand and has a positional advantage which enables them to detect any problems faced by the Indonesian migrant workers in New Zealand.

b. The intermediary position. The agent, in one hand, has a legal relationship with DMS and on the other hand, it also has a MoU with PPTKIS. This position leads to a situation in which agent has vested interests to get involved.

c. The position by law. The agent is recognized as a legal entity in New Zealand. Hence, it has a legal basis or legal power to take a position as a formal and valid entity to carry out facilitation for supporting the negotiations between the Indonesian workers and DMS. They have a better understanding regarding the contractual aspects of New Zealand's companies, in which the Indonesian workers may not fully comprehend. In a more practical way, the agent would bridge any barriers of language, cross-cultural understanding, and lack of legal knowledge of the Indonesian workers. The public-private partnership and cooperation could be instigated as the proper solution for handling any legal issue with regards to placement of Indonesian workers under the RSE scheme.

\section{Conclusions and Recommendations}

\subsection{Conclusion}

The Recognised Seasonal Employer (RSE) can be viewed as a great policy scheme, with subsequent opportunity, for Indonesian peoples to exercise their right to work and at the same time, to increase their standard of living by participating in the scheme. So far, there have been no factual violations against Indonesian migrant workers' rights under the RSE scheme. However, there is also no reason for the government of Indonesia to decrease its efforts to protect the Indonesian

75 Act No. 39 Year 2004 concerning the Placement and Protection of Overseas Indonesia Workers, Art. 77 (1) and (2). 
migrant workers, as the facts show the low performance of some of the stakeholders, like Private Indonesian Employment Placement Company (Perusahaan Pengerah Tenaga Kerja Indonesia Swasta/PPTKIS), remain an obstacle to become clean and trusted procedure. Instead of the moral standards and political commitment, there is a commitment through various kinds of international legal instruments, conventions and declarations, which are then transformed into Indonesian domestic law. The analysis of the aspects of public and private laws found that substance of the employment contract between Indonesian workers and the New Zealand company under the RSE scheme have upheld general principles of employment contract and have fulfilled many of the requirements as stipulated in New Zealand Acts and to some extents, Indonesian laws. This study found that on one hand, New Zealand laws have already covered all aspects of workers and determined New Zealand's government obligation to oversee the employment agreements. On the other hand, Indonesian law and regulations do not explicitly cover the issue of protection of the Indonesian workers who work in New Zealand under the RSE scheme.

In a more practical way, some breakthroughs were made to enable the placement of Indonesian workers in New Zealand and would certainly give the Indonesian law and regulations flexibility in its interpretation. Some commonly performed practices by state and non-state actors in response to the performance of the placement of migrant workers under the RSE Scheme may be adopted by the government of Indonesia for satisfying the standard. Hence, Indonesia may able to place Indonesian migrant workers under the RSE scheme in a more efficient manner. All stakeholders, including the Indonesian workers who work in companies in New Zealand, the Indonesian Ministry of Man Power, National Agency for the Placement and Protection of Migrant Workers (Badan Nasional Penempatan dan Perlindungan Tenaga Kerja Indonesia/BNP2TKI), the Indonesian Embassy in New Zealand, PPTKIS, and the New Zealand company (employer) may take their position in a more efficient manner and comply with the rules and guidelines provided by international and domestic legal instruments.

\subsection{Recommendations}

In reviewing the practice of placement of Indonesian migrant workers under the RSE scheme, it is highly recommended to:

a. The Indonesian Government, in particular, the Ministry of Man Power. From the utilitarian theoretical perspective, the law should be modified in order to increase the advantage and benefit to greater society, in this context, the Indonesian migrant workers and the candidates who expect for better living standards in their lives. Therefore, the government should implement a policy that can accommodate the interests of the Indonesia migrant workers under the RSE scheme to enhance the employment contract in accordance with the terms of the letter of offer and contract given by the company. This can be done 
by stipulating the minimum requirements in the initial approvement process and allowing for flexibility in negotiating other aspects with potential employees.

b. Both Indonesia and New Zealand governments, due to the complexity and tight timeframes of the recruitment process, firmly need to create a bilateral agreement to streamline the application processes and to make the application approval process quicker and more efficient.

c. The Indonesian government, through Indonesian official representatives in New Zealand, should play a more progressive role to visit, inspect, and if required, to enforce the conditions of contract on its own citizens whilst working in New Zealand. This would not only allow the better understanding of the program for the Indonesian Government but would also serve to better protect the Indonesian citizens and to prevent exploitation by any potentially unscrupulous employers.

d. PPTKIS should establish a mechanism of legal protection for Indonesian migrant workers and coordinate its monitoring activities under RSE program. This includes recognition of the workers Under the RSE scheme who do not have a certificate of competence as formally required by Indonesian law.

e. An agent acting on behalf of the RSE employee should be granted appropriate legal standing before both New Zealand and Indonesian law in order to enable them providing an advocacy role for workers.

\section{Acknowledgement}

Authors would like to acknowledge the role of Made Subha Karma Resen, Lecturer at Faculty of Law Udayana University who supervised authors during the research conducted in Bali in 2015 and committees of the legal research collaboration that jointly organized by Faculty of Law Udayana University and Charles Darwin University School of Law; Setyo Budiwardoyo, Head Section of Information and Immigration Communication Means, for the interview in Denpasar on 1st December 2015; Indonesian Officials who work for Indonesian migrant workers; and all Board of Management and Staffs of DMS-Pro Growers, New Zealand. 


\section{BIBLIOGRAPHY}

\section{Book}

Artadi, I. Ketut, and I Dewa Nyoman Rai Asmara Putra. Implementasi KetentuanKetentuan Hukum Perjanjian ke dalam Perancangan Kontrak. Denpasar: Udayana University Press Udayana, 2010.

Jhingan ML, Ekonomi Pembangunan dan Perencanaan. Jakarta: Raja Grafindo Persada, 2008.

Nonnenmacher, Sophie, Free Movement within the ASEAN", in Migration, Free Movement and Regional Integration, edited by Sonja Nita, Antoine Pécoud, Philippe De Lombaerde, Kate Neyts and Joshua Gartland, 347-393. Paris: UNESCO - UNU-CRIS, 2017.

Putra, Ida Bagus Wyasa, Teori Hukum dengan Orientasi Kebijakan (Policy-oriented Theory of Law), Denpasar: Udayana University Press, 2016.

Sugianto, Fajar, Economic Approach to Law: Seri Analisis Ke-ekonomian tentang Hukum. Jakarta: Kencana Prenada Media Group, 2013

Wicaksono, Frans Satriyo. "Panduan Lengkap Membuat Surat-surat Kontrak.” Jakarta: Visi Media, 2008.

Winters, L.A, New Zealand's Recognised Seasonal Employer Scheme: An Object Lesson in Policy Making - But for Whom? Toronto, Geneva and Brighton: ILEAP, CUTS International Geneva and CARIS, 2016.

\section{Journal Article}

Adharinalti, "Perlindungan terhadap Tenaga Kerja Indonesia Irregular di Luar Negeri (Protection of Irregular Indonesian Workers in Overseas)", Jurnal Rechtsvinding: Media Pembinaan Hukum Nasional 1, no.1 (2012) : 157-173

Bedford, Charlotte, Richard Bedford, and Elsie Ho. "Engaging with New Zealand's Recognized Seasonal Employer Work Policy: The Case of Tuvalu." Asian and Pacific Migration Journal 19, no. 3 (2010): 421-445. https://doi. org/ 10.1177/011719681001900306 
Damiri, Devi Melisa, and Mohammad Benny Alexandri. "Industrial Relations: Comparative Non-standard Employment Relationship in Nigeria and Indonesia." AdBispreneur 2, no. 1 (2017). 79-92. https://doi.org/10.24198/adbispreneur. v2i1.12881

Famulski, Tomasz, "Economic Efficiency in Economic Analysis of Law", Journal of Finance and Financial Law 3, no. 15 (2017): 27-39. http://dx.doi.org/10.18778/23916478.3.15.03

Farbenblum, Bassina. "Governance of Migrant Worker Recruitment: A Rights-based Framework for Countries of Origin." Asian Journal of International Law 7, no. 1 (2017): 152-184. https://doi.org/10.1017/S2044251316000011

Hakim, Luqman, and Anwar Fitrianto. "Political Economy of Sending Domestic Workers Abroad: Case Study of Indonesian Migrant Workers." Mediterranean Journal of Social Sciences 6, no. 4 (2015): 316-322. https://doi.org/10.5901/ mjss.2015.v6n4p316

Hao'uli, Ema. "Triple Wins or Trojan Horse?: Examining the Recognised Seasonal Employer Scheme under a Twail Lens." New Zealand Yearbook of International Law 11 (2013): 183-220.

Hartati, Sawitri Yuli, "Peranan Perusahaan Penempatan Tenaga Kerja Indonesia Swasta (PPTKIS) dalam Perekrutan Calon TKI Ke Luar Negeri Melalui Skema P To P”, Social Justicia 1, no. 1 (2017): 142-160.

Oelangan, Meita Djohan. "Implementasi Perjanjian Kerja Dalam Penempatan Tenaga Kerja Indonesia Ke Luar Negeri.” Pranata Hukum 9, no. 1 (2014): 49-61.

\section{Working Paper}

Gibson, John and David McKenzie,"Development through Seasonal Worker Programs: The Case of New Zealand's RSE Program”, Policy Research Working 6762, The World Bank Development Research Group Finance and Private Sector Development Team, January 2014. http://documents.worldbank.org/ curated/en/502981468059040351/pdf/WPS6762.pdf

\section{Thesis or Dessertation}

Kumar, Ronald Ravinesh. "Migration and Development: The Development Impacts of Short-Term Labour Migration of Ni-Vanuatu Workers to New Zealand", Thesis, Masters of Arts in Development Studies, School of Government, Development and International Affairs Faculty of Business \& Economics Laucala Campus The University of the South Pacific. 2012. 


\section{Report}

Commision of Law of New Zealand, "Electronic Commerce Part One: A Guide for the Legal and Business Community", Report No. 50, Wellington, October 1998, para 50. http://www.lawcom.govt.nz/sites/default/files/projectAvailableFormats / NZLC\%20R50_0.pdf

Department of Labour of New Zealand"Final Evaluation Report of The Recognised Seasonal Employer Policies (2007 - 2009)", New Zealand, 2010

\section{International Instrument}

ASEAN Declaration on the Protection and Promotion of the Rights of Migrant Workers ASEAN Human Rights Declaration

Charter of the Association of Southeast Asian Nations

Convention No.97 concerning Migration for Employment, Annex I Recruitment, Placing and Conditions of Labour of Migrants for Employment Recruited Otherwise than under Government-Sponsored Arrangements for Group Transfer

Convention No.143 concerning Migrations in Abusive Conditions and the Promotion of Equality of Opportunity and Treatment of Migrant Workers

International Convention on the Protection of the Rights of All Migrant Workers and Members of Their Families

Rio Declaration on Environment and Development

\section{National Laws of Indonesia}

The 1945 Constitution of the Republic of Indonesia

Indonesian Civil Code

Act No. 39 Year 2004 concerning the Placement and Protection of Indonesian Overseas Workers

Act No. 6 Year 2011 concerning Immigration

Regulation of the Indonesian Minister of Manpower and Transmigration No: PER.19 / MEN / V / 2006 concerning Implementation of Placement and Protection of Indonesian Overseas Worker 
Circular of Governor of Bali Province No. 562/4729 / III.2 / Disnaker dated July 25, 2005 on the Placement of Indonesian Workers Abroad

\section{National Laws of New Zealand}

Wages Protection Act No. 143 (1983)

Human Rights Act No.82 (1993)

Employment Relations Act No. 24 (2000)

Holidays Act No. 129 (2003)

\section{Private Agreements}

Employment Agreement (Fixed Term), Contract between DMS Progrowers Ltd and Employee, Commencement Date 26 March 2017, Expiry Date 1 Oktober 2017.

Memorandum of Understanding between Lubeck Management Group, Auckland, New Zealand, Yayasan Tangan Pertolongan Bali, Bali, Indonesia and PT. Bali Duta Mandiri, Bali, Indonesia signed December 2015.

\section{Website Content}

Arbi Sumandoyo, Berharap jadi TKI di New Zealand, Aryanto tertipu Rp 20 juta, Merdeka.Com, September 18, 2012 https://www.merdeka.com/jakarta/berharap-jadi-tki-di-new-zeland-aryanto-ketipu-rp-20-juta.html;

Detik News, WNI Diimbau Waspadai Penipuan Tawaran Kerja di Selandia Baru, January 27, 2010, https://news.detik.com/berita/1287486/wni-diimbauwaspadai-penipuan-tawaran-kerja-di-selandia-baru

Direct Management Services. History. http://www.dms4kiwi.co.nz/who-we-are/ history/

Kementerian Luar Negeri Indonesia. Selandia Baru Sambut Baik 115 Tenaga Kerja Indonesia. https://www.kemlu.go.id/id/berita/siaran-pers/Pages/SelandiaBaru-Sambut-Baik-115-Tenaga-Kerja-Indonesia.aspx

\section{Interview}

Interview with Setyo Budiwardoyo, Head Section of Information and Immigration

Communication Means, Interview by Authors, Denpasar, December 1, 2015. 